\title{
AKTIVITAS ANTIBAKTERI EKSTRAK DAUN SINGKONG (Manihot esculenta Crantz.) TERHADAP Shigella sp.
}

\author{
Auronita Puspa Pratiwi \\ Poltekkes Kemenkes Pangkalpinang \\ Email: auronitapuspa@gmail.com
}

\begin{abstract}
Antibacterial Activity of The Leaf Extract of Cassava (M. esculenta) against Shigella sp. Shigella sp is a Gram-negative bacteria are the main cause of diarrheal disease which is a major cause of children morbidity and mortality in developing countries, including in Indonesia. One of medicinal plants used to treat diarrhea are cassava (Manihot esculenta Cranz.) leaves which contains flavonoids, saponins and tannins that are known has antibacterial activity. This study aims to determine the antibacterial activity of the leaf extract of cassava (M. esculenta) against Shigella $s p$. This study used discussion diffusion method for measuring inhibition of cassava leaf extract against Shigella $s p$. The extract used was 40\%, 50\%, 60\%, 70\% and 80\%. After incubation for 24 hours, the diameter of inhibitory zone around the disc were measured and regresi linier analyzed to determine the effect of the extract on the inhibition of bacterial growth. Results showed that the inhibition of the growth of Shigella sp by Cassava leaf extract was in weak to moderate category. Increasing concentrations of the extract effect on increasing the diameter of inhibition zone.
\end{abstract}

Keywords: Cassava leaves extract, Shigella sp, inhibition activity

\begin{abstract}
Abstrak: Aktivitas Antibakteri Ekstrak Daun Singkong (Manihot esculenta Crantz.) terhadap Shigella sp. Shigella sp merupakan salah satu bakteri Gram negatif penyebab utama penyakit diare yang menjadi penyebab utama kesakitan dan kematian pada anak di negara berkembang, termasuk di Indonesia.Salah satu tanaman obat yang digunakan oleh mayoritas masyarakat untuk mengobati diare adalah daun Singkong (Manihot esculenta Cranz.) yang memiliki kandungan flavonoid, saponin dan tanin yang diketahui mempunyai aktivitas sebagai antibakteri. Penelitian ini bertujuan untuk mengetahui aktivitas antibakteri ekstrak daun Singkong (M. esculenta) terhadap Shigella $s p$. Penelitian ini menggunakan metode difusi cakram untuk mengukur daya hambat ekstrak daun singkong terhadap Shigella sp. Konsentrasi ekstrak yang digunakan adalah 40\%, 50\%, 60\%, 70\%, dan 80\%. Setelah inkubasi selama 24 jam, diukur diameter zona hambat di sekitar cakram. Data dianalisis regresi linier untuk mengetahui pengaruh ekstrak terhadap penghambatan pertumbuhan bakteri. Hasil penelitian menunjukkan adanya penghambatan pertumbuhan Shigella $s p$ kategori lemah sampai sedang oleh ekstrak daun Singkong. Peningkatan konsentrasi ekstrak berpengaruh pada peningkatan diameter zona hambat.
\end{abstract}

Kata Kunci: Ekstrak Daun Singkong, Shigella sp, daya hambat

Tanaman herbal masih merupakan pilihan utama yang digunakan dalam pengobatan di beberapa belahan dunia (Al-Rubiay et al., 2008). Metabolit sekunder yang dihasilkan tanaman telah diakui memiliki banyak aktivitas farmakologi (Rahmoun et al., 2013). Penyakit yang sering diobati dengan tanaman herbal salah satunya adalah infeksi yang disebabkan oleh bakteri (Borade et al., 2011).

Shigella sp merupakan salah satu bakteri Gram negatif penyebab utama penyakit diare (Ranjbar et al., 2008). Diare adalah penyebab utama kesakitan dan kematian pada anak di negara berkembang, termasuk di Indonesia. Alcoba-florez et al. (2005) mengungkapkan bahwa $69 \%$ dari semua infeksi dan $61 \%$ kematian yang terkait Shigella sp. terjadi pada anak usia $<5$ tahun. Walaupun persentase diare sebagai penyebab kematian pada anak di Indonesia dan negara-negara berkembang lainnya cenderung menurun tetapi Organisasi Kesehatan Dunia (WHO) memprediksikan pada tahun 2025 masih akan terjadi 5 juta kematian pada anak usia kurang dari umur lima tahun akibat diare (Nailul, 2013).

Salah satu tanaman obat yang digunakan oleh mayoritas masyarakat untuk mengobati diare adalah daun Singkong (Manihot esculenta Cranz.) yang memiliki kandungan flavonoid, saponin dan tanin. Senyawa-senyawa tersebut diketahui mempunyai aktivitas sebagai antibakteri (Miladiyah, dkk., 201; Nailul, 2013). 
Berdasarkan hal tersebut, maka perlu penelitian untuk mengetahui aktivitas antibakteri ekstrak daun Singkong (M. esculenta) terhadap Shigella $s p$.

\section{METODE PENELITIAN}

Bahan yang digunakan dalam penelitian ini adalah simplisia daun Singkong, isolat bakteri Shigella sp, etanol 70\%, aquadestillata, media Nutrient Broth (NB), dan media Nutrient Agar (NA).

Simplisia daun singkong diekstraksi dengan metode maserasi yang dilanjutkan dengan evaporasi. Sebanyak $1 \mathrm{~kg}$ simplisia dimasukkan ke dalam wadah kemudian ditambah etanol $70 \%$ hingga bahan terendam, kemudian disimpan di tempat yang terlindung dari cahaya matahari sambil sesekali diaduk, biarkan selama 3-5 hari. Kemudian ekstrak daun Singkong dipisahkan melalui proses penyaringan. Perendaman dengan etanol $70 \%$ diulangi sebanyak 3 kali sampai diperoleh hasil ekstrak yang bening. Selanjutnya ekstrak diuapkan menggunakan rotary evaporator hingga diperoleh ekstrak kental. Ekstrak yang diperoleh dibuat larutan dengan konsentrasi $40 \%, 50 \%, 60 \%, 70 \%$ dan $80 \%$ dengan penambahan akuades.

Daya hambat ekstrak diukur menggunakan metode difusi menggunakan kertas cakram steril yang masing-masing dicelupkan $\mathrm{ke}$ dalam ekstrak daun Singkong (M. esculenta) dengan berbagai konsentrasi selama 30 menit. Kemudian kertas cakram diambil dengan bantuan pinset dan diletakkan dalam cawan petri steril dan dibiarkan kering pada suhu kamar.

Selanjutnya, $1 \mathrm{ml}$ bakteri Shigella $s p$ dimasukkan dalam cawan petri yang telah berisi media Nutrient Agar (NA) kemudian disebar menggunakan batang penyebar. Kertas cakram yang telah direndam di dalam ekstrak daun Singkong (M. esculenta) dengan berbagai konsentrasi diletakkan di atas permukaan media NA sambil sedikit ditekan. Sebagai control positif digunakan Kloramfenikol. Inkubasi pada suhu $37^{\circ} \mathrm{C}$ selama 24 jam. Kemudian dilakukan pengamatan dan pengukuran diameter hambat bakteri Shigella sp menggunakan jangka sorong.

\section{HASIL}

Ekstrak yang digunakan dalam uji aktivitas antibakteri terhadap Shigella sp. Dibuat dalam konsentrasi $40 \%, 50 \%, 60 \%, 70 \%$ dan $80 \%$, masing - masing dengan 3 kali pengulangan. Sebagai kontrol positif digunakan Kloramfenikol $250 \mathrm{mg}$ dan aquadest sebagai kontrol negatif. Setelah diinkubasi selama 24 jam dengan suhu $37^{\circ} \mathrm{C}$, sampel menunjukkan adanya aktivitas antibakteri dengan zona hambat berbeda, seperti tercantum pada Tabel 1 .

Tabel 1. Hasil Pengamatan Diameter Zona Hambat

\begin{tabular}{llccccc}
\hline \multirow{2}{*}{ No } & \multirow{2}{*}{ Bahan Uji } & \multirow{2}{*}{ Konsentrasi } & \multicolumn{3}{c}{ Diameter Hambat (mm) } & Rata-rata Diameter Hambat \\
\cline { 3 - 5 } & & & P1 & P2 & P3 & $(\mathrm{mm})$ \\
\hline 1 & Kontrol (+) & 13,55 & 13,32 & 13,74 & 13,54 \\
2 & Ekstrak Daun Singkong & $40 \%$ & 1,4 & 1,6 & 1,9 & 1,63 \\
& $50 \%$ & 2,4 & 2,6 & 2,8 & 2,6 \\
& $60 \%$ & 3,5 & 3,92 & 4,34 & 3,92 \\
& $70 \%$ & 5,3 & 5,6 & 5,79 & 5,56 \\
& $80 \%$ & 6.24 & 6,64 & 6,82 & 6,6 \\
\hline
\end{tabular}

Keterangan

P1 : Perlakuan ulangan 1

P2 : Perlakuan ulangan 2

P3 : Perlakuan ulangan 3

\section{PEMBAHASAN}

Berdasarkan penelitian yang telah dilakukan, ekstrak Daun Singkong (M. esculenta) memiliki daya hambat terhadap Shigella $s p$ dalam kategori penghambatan lemah hingga sedang. Peningkatan konsentrasi ekstrak berpengaruh pada peningkatan diameter zona hambat yang terbentuk, seperti yang tampak dalam grafik pada Gambar 1.

Uji Regresi Linear digunakan untuk melihat hubungan antara Ekstrak Daun Singkong 
(M. esculenta) terhadap pertumbuhan bakteri Shigella sp. Pada uji Regresi Linear nilai signifikansi $<$ p-value $(0,05)$, yang berarti bahwa Ekstrak Daun Singkong (M. esculenta) berpengaruh terhadap pertumbuhan bakteri Shigella $s p$. Nilai $\mathrm{R}^{2}$ sebesar 0,933 atau $93,3 \%$ (mendekati 100\%) menunjukkan bahwa secara statistik kedua variabel berhubungan, artinya peningkatan konsentrasi ekstrak Daun Singkong berpengaruh terhadap peningkatan diameter zona hambat yang terbentuk. Berdasarkan persamaan regresi diketahui bahwa peningkatan $10 \%$ konsentrasi ekstrak daun Singkong, akan meningkatkan diameter zona hambat terhadap Shigella sp. sebesar $1,25 \mathrm{~mm}$.

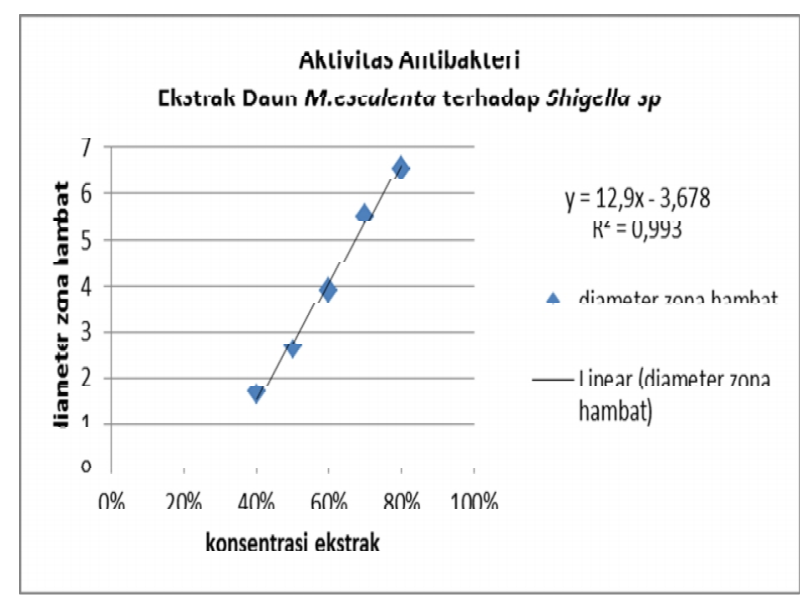
Gambar 1. Hasil Pengukuran Diameter Zona
Hambat

Kandungan pada daun Singkong yang diduga berperan sebagai antibakteri antara lain

\section{Daftar Pustaka}

Ainurrohmah, A., E. Ratnasari, L.Lisdiana. 2013. Efektivitas Ekstrak Daun Binahong (Anredera cordifolia) terhadap Penghambatan Pertumbuhan Bakteri Shigella flexneri dengan Metode Sumuran. LenteraBio 2(3): 233 - 237

Alcoba-Flozen, J., Perez-Roth, E., GonzalezLinares, S. \& Mendez-Alvarez, M. 2005. Outbreak of Shigella sonnei in Rural Hotel in Lagomera, Canary Insland, Spain, International Microbiology, 8: 133-136.

Al-Rubiay, K.K., Jaber, N.N., Al-Mhaawe B.H. \& Alrubaiy, L.K. 2008. Antimicrobial Efficacy of Henna Extracts. Oman Medical Journal. 23 (4): 253-256.

Borade, A.S., Kale, B.N. \& Shete, R.V. 2011. A Phytopharmacological Review on Lawsonia flavonoid, saponin, dan tanin (Aulia, 2013). Beberapa penelitian menunjukkan aktivitas flavonoid, saponin, tannin, sebagai penghambat pertumbuhan bakteri Gram negatif, seperti bakteri Shigella sp. Dinding sel bakteri Gram negatif memiliki susunan dinding sel yang lebih komplek yang memiliki kandungan lipid yang lebih tinggi yaitu $11-22 \%$ dan akan lebih bersifat non polar sehingga akan lebih mudah ditembus oleh senyawa antibakteri yang bersifat non polar (Hidayathulla et al., 2001; Jawetz et al., 2001; Pelczar \& Chan, 1988). Mekanisme penghambatan pertumbuhan mikroorganisme oleh senyawa tersebut secara umum ialah dengan menyebabkan kerusakan dan mengganggu fungsi membran sel (Cushnie, 2005 dalam Taufiq, dkk., 2015).

Flavonoid dapat membentuk senyawa kompleks dengan protein ekstraseluler. Hal ini akan menyebabkan lapisan dinding sel tidak terbentuk secara utuh. Kerusakan dinding sel dapat menyebabkan perubahan permeabilitas membran sel sehingga menghambat kerja enzim intraseluler dan air masuk ke dalam sel secara tidak terkontrol (Robinson, 1995 dalam Ainurrohmah, 2013).

Saponin dapat berdifusi melalui membran kemudian mengikat sitoplasma sehingga mengganggu dan mengurangi kestabilan membran dan menyebabkan sitoplasma bocor keluar dari sel. Hal tersebut pada akhirnya dapat mengakibatkan kematian bakteri (Taufiq, dkk., 2015).

inermis (Linn.), International Journal of Pharmacy \& Life Sciences, 2: 536-541.

Hidayathulla, S., Chandra, K. \& Candrashekar, K.R. 2001. Phytochemical Evaluation and Antibacterial Activity of Pteropermum difersifolium Blume, International Journal of Pharmacy and Pharmaceutical Sciences. 3 (2): 165-167.

Jawetz, E., Melnick, J.L. \& Adelberg, E.A. 2005. Mikrobiologi Kedokteran, diterjemahkan oleh Bagian Mikrobiologi Fakultas Kedokteran Universitas Airlangga, 233-235 \& 363-364. Jakarta: Salemba Medika.

Juffrie, M. 2010. Buku Ajar GastroenterologiHepatologi Jilid I. Jakarta: Balai Pustaka

Miladiyah I, Dayi F, Desrini S. 2011. Analgesic Activity of Ethanolic Extract of Manihot 
esculenta Crantz Leaves in Mice. Universa Medicina 30(1): 3-10.

Nailul, F . 2013. Uji Aktivitas Antibakteri Ekstrak Etanol Daun Pare (Momordica charantia Linn). Skripsi. Universitas Jember

Pelczar, M.J. \& Chan, E.C.S. 2005. Dasar-Dasar Mikrobiologi. Diterjemahkan R.S.Hadioetomo. Jakarta: Universitas Indonesia press.

Sintia, M.S.P, Murhananto. 2004. Memanfaatkan Tanaman Sayur untuk Mengatasi Aneka Penyakit. Jakarta: Agromedia Pustaka
Suprapti, L. 2005. Tepung Tapioka: Pembuatan dan Pemanfaatan. Yogyakarta: Kanisius

Tjitrosoepomo, G. 2005. Taksonomi Tumbuhan (Spermatophyta). Yogyakarta: UGM press

Warnaini, C. 2013. Uji Efektifitas Ekstrak Kunyit Sebagai Antibakteri terhadap Bacillus sp dan Shigella dysentriae secara in vitro. Universitas Padjajaran, Bandung

World Health Organization. 2005. The Treatment of Diarrhea: A Manual For Physicians and Other Senior Health Worker. Geneva: WHO press 